\title{
Effect of replacement of green grass by jackfruit leaf (Artocarpus heterophyllus) on the performance of Black Bengal goats of Bangladesh
}

\author{
MA Akbar, MA Samad \\ Dept of Animal Nutrition, Bangladesh Agricultural University, Mymensingh 2202, Bangladesh
}

Twelve male yearling goats of similar live weights were randomly divided into three groups (A, B and C) of four animals. Three diets : German grass (Echinocloa grousgallh)+ wheat bran+ molasses $\left(T_{1}\right)$, German grass+ Jackfruit (Artocarpus heterophyllus) + wheat bran+ molasses $\left(\mathrm{T}_{2}\right)$ and Jackfruit leaf+ wheat bran+ molasses $\left(T_{3}\right)$ - were fed to the three groups respectively. Grass or leaf was given ad libitum in $\mathrm{T}_{1}$ and $\mathrm{T}_{3}$ groups.

Dry matter (DM) content $(\mathrm{g} / \mathrm{kg})$ of tree leaf (328) was higher than that of green grass (200) which has also been reported by Akbar and Alam (1991, Small Rum Res, 6, 25-30). Crude protein (CP) content $(\mathrm{g} / \mathrm{kg})$ of Jackfruit leaf (123) was higher than that of German grass (81). Intake of German grass $\left(T_{1}\right)$ as a sole roughage was slightly higher than that of
Jackfruit leaf $\left(T_{3}\right)$. Total feed intake among different groups were not very different.

Digestibility of organic matter (OM) and Crude fibre (CF) were similar but that of CP was higher $(P<0.05)$ in $T_{1}$ than in $T_{3}$. There was no significant difference in the digestibility of $\mathrm{CP}$ between $T_{1}$ and $T_{2}$.

Growth was similar between grass and tree leaf fed animals but was significantly $(P<0.05)$ higher in animals fed on mixed diet (grass + leaf). Feed conversion efficiency (FCE) was the highest for the mixed diet followed by sole grass and sole leaf diets respectively with nonsignificant differences.

In conclusion it may be said that green grass can be partially or fully replaced by Jackfruit leaf in the diet of goat in the period of grass scarcity.

\section{Attributes}

DM intake $(\mathrm{g} / \mathrm{d})$

DM intake ( $\mathrm{g} / \mathrm{kg} \mathrm{W}^{0.75}$ )

Dig OM intake $(\mathrm{kg} / \mathrm{d})$

COD of OM (\%)

COD of CF $(\%)$

COD of CP (\%)

Live wt gain $(g / d)$

FCE (kg feed/kg gain)

\section{A}

$$
\begin{gathered}
411.0 \pm 2.0^{a} \\
63.13 \pm 0.95^{a} \\
0.25 \\
66.0 \pm 1.0 \\
67.0 \pm 1.2 \\
68.4 \pm 1.10^{a} \\
53.21 \pm 0.68^{a} \\
7.73 \pm 0.41
\end{gathered}
$$

$\bar{B}$

$$
\begin{gathered}
398.8 \pm 2.6^{b} \\
65.89 \pm 1.1^{a b} \\
0.24
\end{gathered}
$$

$65.7 \pm 1.7$

$66.9 \pm 1.0$

$67.9 \pm 0.98 \mathrm{ab}$

$58.12 \pm 0.96^{b}$

$6.85 \pm 0.45$
C $400.7 \pm 3.1^{\mathrm{a}}$ $68.38 \pm 1.4^{\circ}$ 0.23

$64.1 \pm 1.1$ $66.5 \pm 1.3$ $64.4 \pm 1.33^{\mathrm{b}}$ $50.1 \pm 0.90^{a}$ $8.00 \pm 0.90$

COD : Coefficient of digestibility ; Dig : Digestible. 